\title{
Mediated generalization: Replicated and reinterpreted ${ }^{\prime}$
}

\author{
JEFFERY J. FRANKS AND JAMES J. JENKINS \\ CENTER FOR RESEARCH IN HUMAN LEARNING, UNIVERSITY OF MINNESOTA
}

Wickens \& Briggs (1951) showed that response transfer found in human preconditioning studies could be due to mediation through a common response. The present study replicated their experiment with two additional control conditions. In one condition, Ss made different responses to stimuli during preconditioning. In the other, Ss received no preconditioning. Following operant avoidance conditioning to one stimulus, the other was presented to test for transfer. Wickens and Briggs' results replicated. However, both control groups demonstrated as much transfer as the mediational groups. The mediation interpretation thus appears inadequate.

In stimulus preconditioning studies, pairing of two stimuli has been found to lead to subsequent transfer of a conditioned response from one to the other. Wickens \& Briggs (1951) hypothesized that this transfer was due to mediation through a common response which was conditioned to both stimuli during the preconditioning period. To test this hypothesis, they required Ss to make the same verbal response to two stimuli during preconditioning. As a control, other Ss made the response to only one of the stimuli during this period. Following preconditioning, a finger avoidance response was conditioned to one of the previously presented stimuli. The other stimulus was then presented. Ss who had made a common verbal response to both stimuli showed greater transfer of the avoidance response than Ss who had previously responded to only one of the stimuli. These results provided support for the mediation hypothesis.

The present study is a replication of the above study with two additional control groups. In one control, Ss made different verbal responses to the two stimuli during preconditioning. In the other control, Ss did not receive a preconditioning period at all. According to the mediation hypothesis, transfer should not occur in these controls, since no common response was conditioned to the stimuli. In the present study an operant avoidance response was substituted for the finger avoidance conditioning used by Wickens and Briggs.

Method

Subjects were 60 female volunteers from the introductory psychology course at the University of Minnesota. The apparatus consisted of a buzzer and a light which were presented to Ss on a predetermined schedule. A wrist-band shocking apparatus was used and a button was provided which Ss could press to avoid the shock. The $\mathbf{E}$ was separated from the Ss by a panel.

Prior to the experiment proper, the shock level to be used in avoidance conditioning was determined for each $\mathrm{S}$. The wrist-band was attached and the E gradually increased the shock level. Ss were instructed to stop the $\mathrm{E}$ when the level was as high as they could stand it. The wrist-band remained attached and the shock was maintained at this level throughout the experiment.

The $60 \mathrm{Ss}$ were divided into six groups of 10 each. The groups differed only in the preconditioning task presented to them. The first four preconditioning conditions below are equivalent to the four groups in the Wickens and Briggs study. The last two conditions are the added controls.

(1) L-N: Ss were told that they were going to be given a reaction time task during which they would not be shocked. Ss were asked to say "Now" as quickly as possible when they were presented with a light. A light and a tone were presented separately in random order 15 times each. Stimulus presentations were separated by 10,15 , or $20 \mathrm{sec}$ in a random fashion. Ss were given no instructions regarding the tone. (2) T-N: The same procedure as $\mathrm{L}-\mathrm{N}$ was used except that Ss were told to say "Now" to the tone rather than the light. As above, there were no instructions concerning the light.

(3) $\mathrm{L}-\mathrm{N} T-\mathrm{N}$ : This condition was similar to $\mathrm{L}-\mathrm{N}$ except that Ss were told to say "Now" when either the light or the tone was presented.

(4) LT-N: In this condition the light and tone were presented simultaneously 15 times at random intervals of 10,15 , or $20 \mathrm{sec}$. Ss were instructed to say "Now" as quickly as possible when the tone and light came on.

(5) L-L T-T: This condition was similar to $\mathrm{L}-\mathrm{N}$ except that Ss were told to say "Light" when the light was presented and to say "Tone" to the tone.

(6) 0: This group received no preconditioning task. They went immediately to the conditioning task after the initial adjustment for shock level.

Following preconditioning, all groups received the same avoidance conditioning task. Ss were told they would be shocked at different times and that they could avoid the shock by pressing the button in front of them within 3 sec before the shock was due to occur. No mention was made of the tone, the light, or the time intervals between shocks. The tone was then presented 25 times at random intervals of 15,25 , or $35 \mathrm{sec}$. The Ss were shocked $3 \mathrm{sec}$ after the tone if they had not pressed the button. The light was never presented during the conditioning task. 
Table 1

Number of Ss at Each Response Frequency by Groups

Response Frequencies to the Light

\begin{tabular}{|c|c|c|c|c|c|c|c|c|c|c|}
\hline Group & 0 & 1 & 2 & 3 & 4 & 5 & 6 & 7 & 8 & 9 \\
\hline $\mathrm{L}-\mathrm{N}$ & 8 & - & -. & -. & - & - & $\cdots$ & 1 & 1 & - \\
\hline T-N & 10 & - & - & 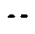 & -- & -- & -- & -- & $=-$ & $=$ \\
\hline L-N T-N & 5 & $\cdots$ & - & $\cdots$ & -. & $\cdots$ & -- & 1 & - & - \\
\hline LT-N & 3 & - & -. & - & - & $\cdots$ & - & - & - & 3 \\
\hline L-L T-T & 1 & 1 & $\cdots$ & $\cdots$ & - & - &.- & - & - & 1 \\
\hline $\mathrm{O}$ & 5 & -. & -. & -- & - & - & -. & - & - & - \\
\hline
\end{tabular}

Following the conditioning task, the light was presented, again at intervals of 15,25 , or 35 sec. There was no break in procedure between the last tone presentation and the first light presentation. The light was presented 10 times. No shock was presented during these 10 trials.

Resulits

All Ss learned the tone-shock contingency and were making avoidance responses to the tone within 12 tone-shock presentations. The majority of Ss learned in less than five tone-shock presentations.

The results of interest to the common-response mediation hypothesis concern the number of avoidance responses (button pushes) to the light in the test trials. Responses to the light generally occurred in an allor-none fashion; i.e., most Ss either made zero or 10 responses (Table 1 ). Since responding appeared to be essentially dichotomous, Ss were classified into two groups, those who responded five or more times to the light and those who responded four or less times to the light. This resulted in a 2 by 6 matrix (response groups by treatment groups). A $x^{2}$ test of significance indicated that there was an overall significant relationship between treatments and responses to the light $\left(X^{2}=18.38\right.$, df $\left.=5, p<.005\right)$.

Further tests on contrasts between treatments were not run since the response measure did not appear to be continuous and the validity of such tests is questionable.

In general the experiment supports the findings of Wickens and Briggs, but not their interpretation. $\mathrm{L}-\mathrm{N}$, $\mathrm{T}-\mathrm{N}, \mathrm{L}-\mathrm{N} T-\mathrm{N}$, and $\mathrm{LT}-\mathrm{N}$ are equivalent to the groups in the Wickens and Briggs study. The groups which made a common response during preconditioning ( $L-N$ T-N and LT-N) showed a greater transfer of the avoidance response to the light (means $=4.7$ and 6.7 , respectiveiy) than $\mathrm{L}-\mathrm{N}$ and $\mathrm{T}-\mathrm{N}$, which did not rem quire a common response (means $=1.5$ and 0.0 , respectively). However, in $L-L T-T$ where different responses were made in preconditioning, the mean number of responses on the transfer task (mean $=8$ ) was clearly greater than $\mathrm{L}-\mathrm{N}$ and $\mathrm{T}-\mathrm{N}$. In addition, there is some indication that $L-L \quad T-T$ resulted in greater transfer than $\mathrm{L}-\mathrm{N}$ T-N and LT-N which should have been the ideal conditions for transfer to occur by the mediation hypothesis. In even greater conflict with the hypothesis are the results from Group 0 (mean responses to light $=5.0$ ). These too show a greater transfer to the light than $\mathrm{L}-\mathrm{N}$ and $\mathrm{T}-\mathrm{N}$, yet a mediating common response could not have formed between the light and the tone in this condition. Discussion

The results of the present study question the adequacy of a common-response mediation interpretation of preconditioning transfer effects, such as that proposed by Wickens and Briggs. The data of $\mathrm{L}-\mathrm{L} \mathrm{T}-\mathrm{T}$ might be fitted into this explanation if one is willing to accept that the common response consisted of "verbalization" to the stimuli and not a specific verbalization. However, even this reinterpretation is insufficient to account for Group 0, where no common response of any kind was possible.

The most limited interpretation that fits these data is that in this threatening situation, Ss treat all salient stimuli as cues to respond unless they have been explicitly trained to ignore them.

Reference

WICKENS, D. D., \& BRIGGS, G. E. Mediated stimulus generalization in sensory preconditioning. J. exp. Psychol, 1951, 42, 197-200.

Note

1. This research was supported by grants to the Center for Research in Human Learning from the National Science Foundation (GS 1761), the National Institute of Child Health and Human Development (PO 1-HD 01136) and the Graduate School of the University of Minnesota. Mr. Franks is a predoctoral trainee of the Center under a National Institute of Child Health and Human Development training grant (HD-00098). 